\title{
ZŁOŻONY SYSTEM UJĘCIA ODCIEKÓW ZE STAREGO SKŁADOWISKA ODPADÓW JAKO ELEMENT BEZPIECZEŃSTWA GEOTECHNICZNEGO
}

\begin{abstract}
Odcieki w składowisku powstają przede wszystkim w wyniku przenikania wód opadowych przez odpady. W przypadku starych składowisk bez uszczelnienia podstawy, wymagane jest zaprojektowanie złożonego systemu drenażowego. Przebieg ciągów drenażowych powinien być dostosowany do kształtu bryły, tras komunikacyjnych i sposobu zagospodarowania odcieków. Drenaż powinien być tak zaprojektowany aby spełniał wymogi hydrauliczne przez cały okres aktywności biochemicznej składowiska, tj. przez co najmniej 50 lat, dlatego zasadniczego znaczenia nabiera odpowiednie zabezpieczenie drenażu warstwami filtracyjnymi, mineralnymi lub z geowłóknin. W artykule przedstawiono złożony system ujęcia odcieków z rekultywowanego składowiska Radiowo, przed i po przebudowie. Omówiono bilans ilości odcieków i ich skład, a także wyniki badań geowłókniny zastosowanej jako filtr w rowach retencyjnych. Badania wykazały, że dobór materiałów użytych w systemie ujęcia odcieków stanowi istotny element jego skutecznego działania. Dobrze zaprojektowany i wykonany system ujęcia odcieków jest także jednym z elementów zapewnienia bezpieczeństwa geotechnicznego, bowiem położenie krzywej depresji odcieków na składowisku ma znaczący wpływ na globalną stateczność skarp składowiska.
\end{abstract}

Słowa kluczowe: składowisko odpadów, rekultywacja, odcieki, drenaż, bezpieczeństwo geotechniczne

\footnotetext{
${ }^{1}$ Autor do korespondencji/corresponding author: Eugeniusz Koda, Szkoła Główna Gospodarstwa Wiejskiego w Warszawie, ul. Nowoursynowska 166, 02-787 Warszawa, 225935218, eugeniusz_koda@sggw.pl

2 Anna Miszkowska, Szkoła Główna Gospodarstwa Wiejskiego w Warszawie, ul. Nowoursynowska 166, 02-787 Warszawa, 225935213, anna_miszkowska@sggw.pl

3 Anna Sieczka, Szkoła Główna Gospodarstwa Wiejskiego w Warszawie, ul. Nowoursynowska 166, 02-787 Warszawa, 225935222, anna_sieczka@ @ggw.pl

${ }^{4}$ Paweł Fołtyn, ARPAGEO s.c., ul. Powstania Styczniowego 53A, 05-074 Halinów, 603822431, arpageo@op.pl
} 


\section{Wprowadzenie}

Składowiska odpadów to nietypowe obiekty inżynierskie, należące do najtrudniejszych obiektów budowlanych. Związane jest to przede wszystkim z ich dużą powierzchnią, pojemnością, miąższością oraz długim okresem eksploatacji i negatywnym oddziaływaniem na środowisko. Wyeliminowanie lub znaczne ograniczanie oddziaływania tego typu obiektów na środowisko realizowane jest poprzez prace rekultywacyjne $[2,4,5]$.

Rekultywacja starych składowisk odpadów polega między innymi na zabezpieczeniu wód gruntowych przed zanieczyszczeniem na terenach przyległych, co może być realizowane przez wykonanie pionowej przesłony przeciwfiltracyjnej, której koniecznym uzupełnieniem jest odpowiedni system ujęcia odcieków. Źle działający system odprowadzania odcieków może prowadzić do wysięków na skarpach, co skutkuje zanieczyszczeniem środowiska wodnogruntowego na terenach przyległych oraz możliwością utraty stateczności skarpy. Pozostałe prace rekultywacyjne obejmują m.in. wykonanie systemu odgazowania, ukształtowanie i przykrycie bryły składowiska oraz wprowadzenie na powierzchnię odpowiednio dobranych gatunków roślin [5].

Układ ujmowania i zagospodarowania odcieków ze składowiska zwykle tworzą: drenaże odcieków (na starym składowisku najczęściej przyskarpowe drenaże opaskowe i drenaże palczaste), rowy i zbiorniki do retencjonowania odcieków ze składowiska, elementy systemu recyrkulacji, pompownie do przesyłania odcieków, rurociągi tłoczne oraz systemy rozprowadzania zanieczyszczonych wód na powierzchni składowiska, z możliwością ewentualnego rozcieńczania silnie stężonych odcieków na potrzeby nawodnień roślinności $[3,5$, $8,10,12]$.

W artykule przedstawiono złożony system ujęcia odcieków na składowisku Radiowo. System zabezpieczający przed wydostawaniem zanieczyszczeń ze składowiska składa się z pionowej przesłony przeciwfiltracyjnej oraz systemu ujęcia odcieków z recyrkulacją odcieków, a następnie z odprowadzeniem odcieków do kanalizacji miejskiej [7, 6]. Podczas przebudowy wykonano badania zastosowanych wcześniej geosyntetycznych materiałów filtracyjnych [11].

\section{Charakterystyka obiektu}

Składowisko „Radiowo”, nazywane potocznie „najwyższą górą na Mazowszu" zlokalizowane jest na terenie Gminy Stare Babice i częściowo na terenie Warszawy (Dzielnica Bemowo). Składowisko Radiowo zostało zatwierdzone jako miejsce składowania odpadów komunalnych z terenu Warszawy w 1961 roku. Od początku działania składowisko nie posiadało żadnych systemów zabezpieczających przed zanieczyszczeniem środowiska wodno-gruntowego, dlatego już w pierwszych latach eksploatacji spowodowało to znaczne szkody w środowisku, które narastały z biegiem lat. Od strony południowej i wschodniej 
otoczone jest lasami Parku Leśnego „Bemowo”, zaś od strony północnej składowisko sąsiaduje z zakładem unieszkodliwiania odpadów (d. kompostownią), który położony jest na terenie Dzielnicy Bielany. W odległości ok. $350 \mathrm{~m}$ na północ od kompostowni przepływa ciek Lipkowska Woda, dopływ Kanału Zaborowskiego, a w odległości ok. $550 \mathrm{~m}$ od kompostowni przebiega ul. Arkuszowa, tj. najbliższy pas zabudowy mieszkalnej (domki jednorodzinne i gospodarcze oraz obiekty użyteczności publicznej). Tereny Kampinoskiego Parku Narodowego oddalone są ok. $3 \mathrm{~km}$ na północny-zachód od składowiska [5].

Bryła składowiska w planie zajmuje powierzchnię około 14 ha, a wysokość ponad $60 \mathrm{~m}$. Całkowita kubatura obiektu przekracza 4,5 $\mathrm{mln} \mathrm{m}^{3}$. Od $1992 \mathrm{roku}$ obiekt stał się składowiskiem technologicznym wyłącznie do wbudowywania odsiewów balastowych z kompostowni Radiowo, a od 2012 roku przyjmuje odpady pochodzące $\mathrm{z}$ mechaniczno-biologicznego przetwarzania odpadów komunalnych. Wbudowywane na nim odpady stanowią materiał do kształtowania bryły składowiska. Planowane jest zamknięcie składowiska z końcem 2016 roku i przystosowanie do zagospodarowania jako stoku narciarskiego.

\section{Bilans wodny składowiska}

Bilans wodny składowiska tworzony jest na potrzeby racjonalnej gospodarki wodno-ściekowej oraz do odpowiedniego zaprojektowania systemu odprowadzenia odcieków. Odcieki ze składowisk stanowią silnie zanieczyszczoną chemicznie i biologicznie ciecz, z charakterystyczną zmiennością składu, co ma również znaczenie przy opracowywaniu systemu ich ujęcia i zagospodarowania. W celu zaprojektowania i eksploatacji systemu odprowadzenia odcieków ze składowiska Radiowo opracowano szczegółowy bilans wodny terenu składowiska i kompostowni (Tabela 1).

Tabela 1. Bilans wodny dla składowiska w Radiowie [5]

Table 1. Water balance of Radiowo landfill [5]

\begin{tabular}{|c|c|c|c|c|}
\hline Lp. & Wyszczególnienie & Symbol & Jednostki & Wielkość \\
\hline \multicolumn{5}{|c|}{ Przychód } \\
\hline 1 & Opad na powierzchni 14 ha & $\mathrm{P}$ & $\mathrm{m}^{3}$ & 74340 \\
\hline \multirow[t]{2}{*}{2} & Dopływ z pompowni $\Sigma(\mathrm{P} 1+\mathrm{P} 2)$ & $\mathrm{H}_{2}$ & $\mathrm{~m}^{3}$ & 13500 \\
\hline & Sumowy przychód & $\mathrm{P}+\mathrm{H}_{2}$ & $\mathrm{~m}^{3}$ & 87840 \\
\hline \multicolumn{5}{|c|}{ Rozchód } \\
\hline 3 & $\begin{array}{l}\text { Parowanie } \mathrm{z} \text { intensywnie nawadnianych } \\
\text { powierzchni } 14 \text { ha }\end{array}$ & $\mathrm{E}_{\mathrm{r}}$ & $\mathrm{m}^{3}$ & 91000 \\
\hline \multirow[t]{2}{*}{4} & Zdolność retencyjna & $\Delta \mathrm{R}$ & $\mathrm{m}^{3}$ & 108800 \\
\hline & $\underline{\text { Sumowy rozchód }}$ & $\mathrm{E}_{\mathrm{r}}+\Delta \mathrm{R}$ & & 199800 \\
\hline
\end{tabular}


Po uwzględnieniu zrealizowanego odizolowania obszaru składowiska przesłoną przeciwfiltracyjną, można przyjąć, że równanie bilansu ma postać:

$$
P+H_{2}=E_{r}+\Delta R
$$

Uzyskana z bilansu ilość odcieków była podstawą opracowania projektu odwodnienia składowiska. Bilans wodny składowiska zweryfikowano na podstawie pomiarów prowadzonych w ramach rozruchu technologicznego systemu recyrkulacji.

System zagospodarowania odcieków w ramach recyrkulacji, był eksploatowany na składowisku przez ponad 12 lat i nie wystąpiła potrzeba wywożenia odcieków do miejskich punktów zlewnych. Z uwagi na małą wilgotność odpadów balastowych (poniżej 20\%), składowisko posiadało znaczne zdolności retencyjne w korpusie odpadów, co sprzyjało zagospodarowaniu w ramach recyrkulacji.

\section{System ujęcia odcieków}

\subsection{Przed przebudową}

W latach 1997-98 opracowano projekty budowlane rekultywacji składowiska. W okresie tym w rejonie składowiska i kompostowni nie było jeszcze kanalizacji. Odcieki ze składowiska ujmowane były systemem drenażowym i kierowane do rowów retencyjnych (A i B od strony zachodniej oraz C i D od strony wschodniej i południowej). Z rowów retencyjnych odcieki tłoczono dwiema pompowniami (P1 i P2) do zbiornika szczelnego na koronie składowiska, skąd były rozsączane na koronie i skarpach.

W ramach systemu recyrkulacji wykonano zbiornik retencyjny za kompostownią, pompownię podziemną (P3) z automatycznym sterowaniem oraz rurociąg tłoczny z pompowni do zbiornika podziemnego przy zachodniej skarpie składowiska, z którego odcieki te były tłoczone na koronę i rozprowadzane na skarpy składowiska. Do systemu zagospodarowania odcieków w 2001 roku włączono również podczyszczone wody opadowe z terenu kompostowni, odprowadzane wcześniej do Kanału Zaborowskiego [7]. Schemat pasa rekultywacyjnego przedstawiono na rysunku 1 . Zrealizowany układ miał na celu ujęcie odcieków ze składowiska i nadmiaru wód opadowych z oczyszczalni na terenie kompostowni w ilości ok. $20000 \mathrm{~m}^{3} /$ rok [5], a następnie rozprowadzenie na powierzchni w celu infiltracji do korpusu i odparowania nadmiaru. 


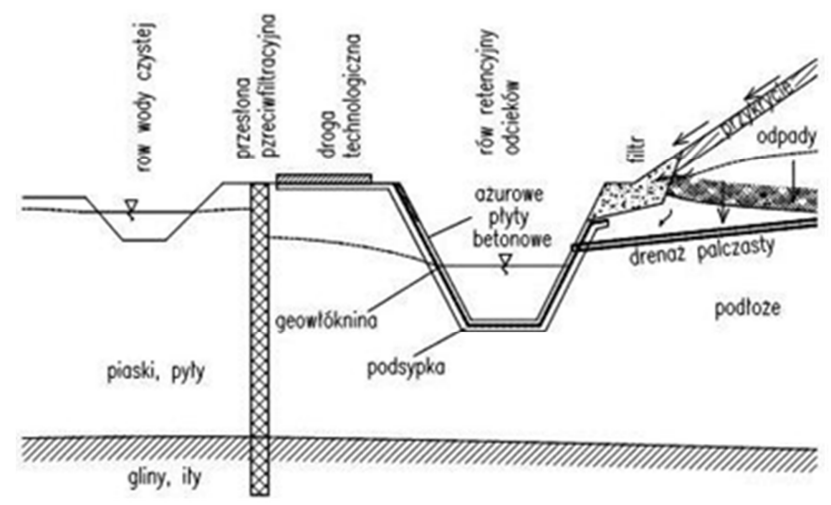

Rys. 1. Pas rekultywacyjny zabezpieczający składowisko przed przebudową [7]

Fig. 1. Leachate drainage system before the re-build [7]

\subsection{Po przebudowie}

W 2011 roku przebudowano system ujęcia i odprowadzenia odcieków, ponieważ pojawiła się możliwość odprowadzenia ich do miejskiej sieci kanalizacyjnej. Istniejące rowy retencyjne wypełnione odciekami, lokalnie o głębokości ponad $2 \mathrm{~m}$, stanowiły zagrożenie dla zwierząt, wydzielały odory, a także stanowiły szpecący element środowiskowy w sąsiedztwie Parku Leśnego „Bemowo”. $\mathrm{Z}$ tego powodu prace rekultywacyjne polegały na zasypaniu istniejących rowów retencyjno - odparowywalnych A i B od strony zachodniej oraz C i D od strony wschodniej i na zastąpieniu ich zamkniętymi rurociągami drenażowymi o średnicy $\varphi 0,3 \mathrm{~m} \mathrm{w}$ obsypce filtracyjnej (Rys. 2). Do rurociągów zostały podłączone wyloty istniejących drenaży palczastych, które wyprowadzają odcieki z podstawy nasypów dociążających skarpy składowiska. Zastosowanie drenaży palczastych miało na celu obniżenie położenia krzywej depresji odcieków w składowisku, ważne z uwagi na stateczność skarp i bezpieczeństwo geotechniczne [6].

Drenaże w miejsce rowów retencyjnych $\mathrm{C}$ i D zostały wykonane w postaci podwójnych rurociągów i doprowadzone do istniejącej pompowni P2 od strony wschodniej, skąd odprowadzają odcieki do zbiornika podziemnego pod pompownią P1 przy skarpie zachodniej, a dalej poprzez zbiornik retencyjny i pompownię tłoczone do kanału ogólnospławnego $\varphi 0,8 \mathrm{~m}$ wzdłuż ul. Arkuszowej, odprowadzającego ścieki do rozbudowanej oczyszczalni ścieków Czajka. Przewód tłoczny między pompownią wschodnią i zachodnią poprowadzono wokół składowiska od strony południowej [6]. Przebudowa systemu ujęcia odcieków stworzyła możliwości zmiany ukształtowania bryły składowiska z kierunkiem rekultywacji jako stok narciarski. 


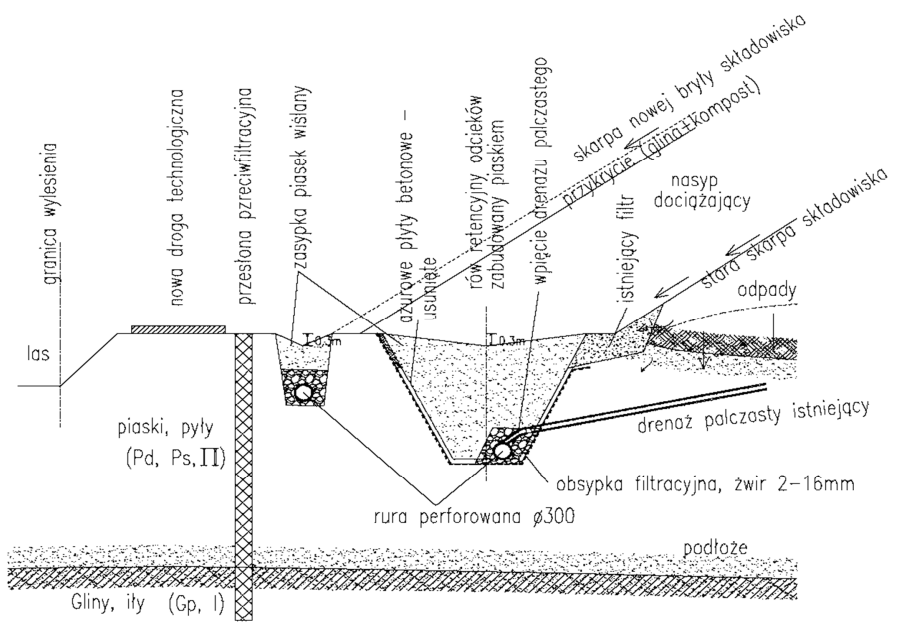

Rys. 2. System ujęcia odcieków po przebudowie

Fig. 2. Leachate drainage system after the re-build

\subsection{Filtry w systemie ujęcia odcieków}

Podczas prac związanych z projektem zamiennym ukształtowania bryły składowiska z 2011 roku [6], pobrano próbki geowłókniny o masie powierzchniowej $500 \mathrm{~g} / \mathrm{m}^{2}$. Geowłókniny były stosowane jako filtr na skarpach rowów retencyjnych od 1998 roku, jednak na niektórych skarpach nastąpiło zakolmatowanie geowłókniny, które było przyczyną „,klawiszowania” płyt umacniających skarpę rowu. Przeprowadzone badania zmiany przepuszczalności zgodnie z normą EN ISO 10776: 2012 [1] i PN-EN ISO 11058:2010 [9], wykazały zmniejszenie przepuszczalności tych materiałów. Zmianę współczynnika przepuszczalności poprzecznej $\mathrm{k}_{\mathrm{g}}$ od naporu hydraulicznego $50 \mathrm{~mm}$ dla próbek geowłókniny nowej i po 15 latach eksploatacji przedstawiono w tabeli 2 [11].

Tabela 2. Wielkości przepuszczalności badanych próbek geowłókniny [11]

Table 2. The values of permeability coefficient of tested nonwoven geotextiles samples [11]

\begin{tabular}{|c|c|c|c|c|}
\hline \multirow{2}{*}{$\begin{array}{c}\text { Obciążenie } \\
(\mathbf{k P a})\end{array}$} & $\begin{array}{c}\text { Współczynnik przepuszczal- } \\
\text { ności poprzecznej } \mathbf{k}_{\mathbf{g}}(\mathbf{m} / \mathbf{s})\end{array}$ & $\begin{array}{c}\text { Zmiana współczynnika } \\
\text { przepuszczalności } \mathbf{k}_{\mathbf{g}}(\%)\end{array}$ \\
\cline { 2 - 5 } & \multicolumn{4}{|c|}{ Geowłóknina } \\
\cline { 2 - 5 } & Nowa & $\begin{array}{c}\text { Po 15 latach } \\
\text { eksploatacji }\end{array}$ & Nowa & $\begin{array}{c}\text { Po 15 latach } \\
\text { eksploatacji }\end{array}$ \\
\hline 0 & $7,9 \cdot 10^{-3}$ & $1,3 \cdot 10^{-3}$ & 100 & 83 \\
\hline 2 & $3,4 \cdot 10^{-3}$ & $6,0 \cdot 10^{-4}$ & 100 & 82 \\
\hline 20 & $3,0 \cdot 10^{-3}$ & $5,0 \cdot 10^{-4}$ & 100 & 83 \\
\hline 200 & $2,1 \cdot 10^{-3}$ & $3,0 \cdot 10^{-4}$ & 100 & 86 \\
\hline
\end{tabular}


Jak wynika z przeprowadzonych badań po 15 latach eksploatacji przepuszczalność poprzeczna zastosowanych geowłóknin zmniejszyła się 6-krotnie. Znaczne zmiany właściwości filtracyjnych badanych geowłóknin spowodowały, że zrezygnowano $\mathrm{z}$ ich stosowania $\mathrm{w}$ przebudowanym systemie ujęcia i odprowadzenia odcieków. Zamiast filtru z geowłókniny, zastosowano filtr mineralny ze żwiru i piasku. Uznano że filtry mineralne dają gwarancję długotrwałego działania systemu bez zagrożenia zamuleniem. Zamulenie filtru może prowadzić do spadku efektywności drenażu, podniesienia poziomu krzywej depresji odcieków w bryle składowiska i pogorszenia warunków stateczności [5].

\section{Wnioski}

1. Budowa skutecznego systemu drenażowego odcieków na starym składowisku powinna być poprzedzona zebraniem niezbędnych danych konstrukcyjnych i materiałowych dotyczących obiektu, w tym składu i ilości odcieków (bilans wodny składowiska).

2. Właściwy dobór materiałów filtracyjnych w systemie ujęcia odcieków stanowi ważny element zapewniający długotrwałe działanie drenażu i zarazem zapewnienia bezpieczeństwa geotechnicznego składowiska odpadów.

3. Przebudowa systemu drenażu odcieków na składowisku Radiowo umożliwiła zmianę ukształtowania bryły i przystosowanie morfologii odpadów zdeponowanych do użytkowania jako stoku narciarskiego, po zamknięciu i rekultywacji składowiska, zapewniając bezpieczeństwo geotechniczne.

\section{Literatura}

[1] EN ISO 10776:2012 Geotextiles and geotextile- related products. Determination of water permeability characteristics normal to the plane, under load.

[2] Jessberger H.J.: Geotechnics of Landfills Design and Remedial Works - Technical Recommendations GLR, Ernst\&Sohn, Berlin 1993.

[3] Jones-Lee A., Lee F. G.: Appropriate Use of MSW Leachate Recycling in Municipal Solid Waste Landfilling, California, 2000.

[4] Koda E.: Remediation of the old embankment sanitary landfills. Geoenvironmental Engineering: Ground Contamination. Thomas Telford ed., London, 1999, pp. 29-38.

[5] Koda E.: Stateczność rekultywowanych składowisk odpadów i migracja zanieczyszczeń przy wykorzystaniu metody obserwacyjnej, Wydawnictwo SGGW, Warszawa, 2011.

[6] Koda E., Laskowski M., Paprocki P., Fołtyn P.: Projekt zamienny ujęcia i zagospodarowania odcieków - Projekt budowlany rekultywacji składowiska odsiewów balastowych w Radiowie. Geoteko Sp. z o.o., Warszawa, 2011.

[7] Koda E., Paprocki P.: Durability of leachate drainage systems of old sanitary landfills. Proc. of the $3^{\text {rd }}$ Intern. Conf. on Geofilters in Geotechnical and Environmental Engineering, 2000, pp. 215-222. 
[8] Lipniacka-Piaskowska A.: Funkcjonowanie składowiska odpadów z recyrkulacją odcieków. Praca doktorska, Zachodniopomorski Uniwersytet Technologiczny, Szczecin 2010.

[9] PN-EN ISO 11058:2010 Geotekstylia i wyroby pokrewne - Wyznaczanie charakterystyk przepuszczalności w kierunku prostopadłym do powierzchni wyrobu.

[10] Renou S., Givaudana J.G., Poulain S., Dirassouyan F., Moulin P.: Landfill leachate treatment: Review and opportunity, Journal of Hazardous Materials, No. 150, 2008, pp. 468-493.

[11] Stępień S., Osiński P., Koda E.: Laboratoryjne badania wodoprzepuszczalności poprzecznej pod obciążeniem geowłókniny eksploatowanej na składowisku odpadów, Acta Scientiarum Polonorum - Architectura, nr 11(4), 2012, s. 41-50.

[12] Zadroga B.: Drenaże wodne w nowoczesnych składowiskach odpadów, Inżynieria Morska i Geotechnika, Nr 1, 1996, s. 65-70.

\section{COMPLEX DRAINAGE SYSTEM IN THE OLD SANITARY LANDFILL AS AN ELEMENT OF GEOTECHNICAL SAFETY}

\section{S u m m a r y}

Leachate in the landfill occurs mainly as a result of infiltration of rainwater through the wastes. In the case of old sanitary landfills without sealing of complex drainage system is required. Drainage systems should be adjusted to landfill slope, communication route and leachate management. Drainage system should meet the hydraulic requirements in all time of biochemical landfill activity, at least 50 years. In that reason adequate protection of the drainage filter layer, mineral or nonwoven geotextile is significant. The paper presents leachate drainage system in the old landfill Radiowo. Leachate balance and composition of leachate as well as results of analyses obtained from laboratory tests of water permeability of exploited nonwoven geotextile samples collected from Radiowo landfill are also presented. The obtained results allowed affirm that properly choice of materials in leachate drainage system is one of the most important elements in designing. Properly designed and performed leachate drainage system is also important in ensuring geotechnical safety due to the position of leachate depression curve has an influence on stability of the landfill slope.

Keywords: sanitary landfill, recultivation, leachate, drainage, geotechnical safety

Przestano do redakcji: 07.06.2016 $r$.

Przyjęto do druku: 30.06 .2016 r.

DOI: $10.7862 / \mathrm{rb} .2016 .62$ 